\title{
The Development of Teaching Materials to Write Report Text Based on Inquiry
}

\author{
Sabrina Pinta Uli Br. Pasaribu \\ Postgraduate Program in Indonesian Language Education \\ Universitas Negeri Medan \\ Medan, Indonesia \\ Email: sabrina.pasaribu8290@gmail.com \\ Tiur Asi Siburian \\ Postgraduate Program in Indonesian Language Education \\ Universitas Negeri Medan \\ Medan, Indonesia \\ Abdurrahman Adisaputera \\ Postgraduate Program in Indonesian Language Education \\ Universitas Negeri Medan \\ Medan, Indonesia
}

\begin{abstract}
Inquiry becomes the right choice to form a good concept. The advantage of an inquiry-based module that improves students' motivation because students can learn by themselves and lessons are divided more equally. This study aims to determine the feasibility of the development of teaching materials to write the text of the results of observations based on inquiry. The feasibility of teaching materials in the form of this module was obtained by the assessment of two material experts and two design experts. This research is a research and development. Model development in this research by using Borg and Gall development model. This instrument includes a closed questionnaire to be assessed using the Likert scale format. The results showed that the teaching materials in the form of developed modules based on inquiry received the "very good" category from the material experts with an average percentage of $85.15 \%$, and the design experts with an average percentage of $86.25 \%$. This indicates that the development of teaching materials to write the report text based on inquiry is declared feasible to be used based on the assessment of material experts and design experts with the "very good"category.
\end{abstract}

Keywords-development; teaching materials; report text; inquiry; module

\section{INTRODUCTION}

Interesting and innovative teaching materials are very important to make and become a demand for every teacher. This is because the work of making teaching materials has a great contribution to the success of the learning process undertaken. In line with that, selection and development of appropriate teaching materials will motivate students to create interesting and enjoyable Indonesian learning [1]. The making or development of teaching materials is actually not a difficult thing to do by the teacher. Unfortunately, this is not easy to manifest for various reasons. The discourse of making this material is due to the limitations of literature reviewing the theme of teaching materials, both in bookstores and libraries, making teachers seem difficult to realize these demands [2]. Therefore, many schools or educational institutions and teachers who use other people's learning materials (authors of book publishers) though often not or less in accordance with needs.

One school that uses other people's learning materials is Gajah Mada Senior High School. This is evidenced by the results of interviews obtained from Indonesian teacher. The learning at this school uses teaching materials in the form of compulsory textbook from the Ministry of Education and Culture. However, this book still has weakness, one of them on the material of Observation Report. The text of the observation report contained in the compulsory textbook still has weaknesses. The weakness is seen in the text material of report text that is not in accordance with the existing syllabus. The non-conformity of the report text contained in this compulsory textbook influences the student's learning outcomes. The value of writing the text of the observation result of the class X students at the Gajah Mada High School in Medan is still low. This low score is seen from 15 students (out of a total of 32 students) scores between 70 - 72 with minimal learning completeness score 75 . Therefore, students need a teaching material to write a report text results that aims to make it easier students in learning Indonesian.

In relation to the above problems, this research is to develop teaching materials to write the report text in the form of modules combined with the inquiry learning model. The inquiry model teaches students to come up with ideas and find solutions to problems they find. The findings are related to student learning environments [3]. Inquiry becomes the right choice to form a good concept. The advantage of an inquirybased module that improves students' motivation because students can learn by themselves and lessons are divided more equally [4]. To support the achievement of learning objectives, teachers must have appropriate learning strategies and media 
used in the lesson [5]. The role of teachers in using appropriate teaching materials will achieve basic competencies and student learning outcomes in all types of learning. This study was conducted only until the limited field trial stage has been validated by material experts and design experts to know the feasibility of teaching materials in the form of this module.

\section{METHOD}

This type of research is research and development $(\mathrm{R} \&$ D). This research and development refers to the theory of teaching materials developed by Borg and Gall. Proposes Borg and Gall's research and development phases are (1) potentials and problems, (2) data collection, (3) developing initial product, (4) initial field testing, (5) product revision, (6) ) field trials, (7) revisions, (8) operational field tests, (9) final product revisions, and (10) product dissemination and implementation [6]. Accorrding to those phares, this research is until fifth phase. Procedural can be done with steps as follows.

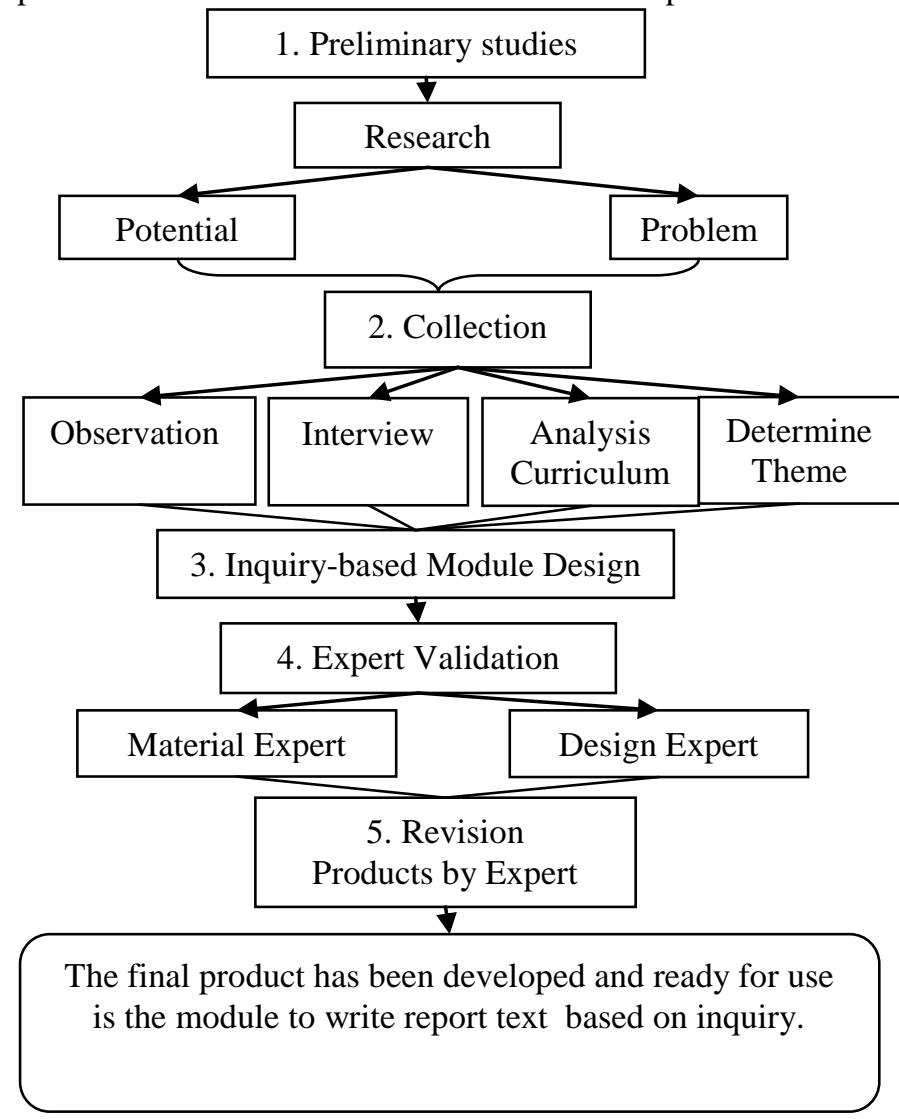

Fig. 1. Procedure of This Research

The instrument of data collection in developing teaching materials in the form of this module is the assessment to assess the product developed. This instrument includes a closed questionnaire to be assessed using the Likert scale format.

\section{RESULTS}

The process of developing instructional materials in the form of this inquiry-based module is done in stages. The stage is the first to analyze the problems and needs in Gajah Mada Senior High School which is the background of this research and development problem by spreading the questionnaire to 2 Indonesian teachers and 32 students of class X at the school The result of requirement analysis is the development of the teaching materials is needed by teachers and students in the learning process to improve the quality of learning. Validation and assessment by a team of material experts and a team of design experts on each aspect of the overall assessment is determined by the average percentage of each category. Analyzing the results aims to determine whether or not the teaching materials in the form of a module to write the report text based on inquiry. The average percentages taken from the assessment results by materials experts and design experts.

\section{A. Product Analysis by Material Expert Team}

The material expert consisting of two experts who assessed the instructional materials in the form of a module to write the report text based on inquiry which have been developed based on three subcomponents consisting of the content feasibility, language, and presentation. The results of the assessment of the material expert team of three three subcomponents are categorized as "very good" with the average percentage of $84.37 \%$ on content, $83.51 \%$ on presentation, and $87.85 \%$ on the language.

\section{B. Product Analysis by Design Expert Team}

A design expert consisting of two experts who assessed instructional materials in the form of a module to write the report text based on inquiry which have been developed based on three subcomponents consisting of module size, module cover design, and module contents design. The results of the assessment of design team of three subcomponents are categorized as "very good" with the average percentage of $87.5 \%$ on module size, $87.5 \%$ on the module cover design, and $85.53 \%$ on module contents design.

\section{CONCLUSION}

The product in the form of validated inquiry module that has been validated through a series of tests and revisions is valid and feasible to be used as additional teaching materials in the process of learning the report text. Authors and Affiliations

\section{REFERENCES}

[1] E.D. Purwitasari, "Pengembangan Model Bahan Ajar Teks Laporan Hasil Observasi untuk Siswa SMK Kelas X", NOSI, vol. 2 No. 4. pp 297 - 304. 2014.

[2] A. Prastowo,. Panduan Kreatif Membuat Bahan Ajar Inovatif: Menciptakan Metode Pembelajaran yang Menarik dan Menyenangkan. Yogyakarta: Diva Press. 2015.

[3] Harmawati, dkk. "Pengembangan Modul Berbasis Inkuiri Disertai Multimedia Interaktif pada Siswa Kelas VII SMP 18 Malang”, Jurnal Pendidikan: Teori, Penelitian, dan Pengembangan, vol. 1 No. 8. pp. 1536 - 1539. 2016. 
[4] Suryaningsih, N. S. "Pengembangan Media Cetak Modul Sebagai Media Pembelajaran Mandiri pada Mata Pelajaran Teknologi Informasi dan Komunikasi”. Tesis: Universitas Negeri Surabaya. 2010.

[5] Juliawati, dkk. "Pembelajaran Menulis Teks Laporan Hasil Observas Berbasis Kearifan Lokalpada Siswa Kelas VII A4 SMP Negeri 1
Singaraja", e-Journal Jurusan Pendidikan Bahasa dan Sastra Indonesia Undiksha, vol. 3 No.1. pp. 1 - 10. 2015.

[6] Sugiyono, Metode Penelitian Pendidikan (Pendekatan Kuantitatif, Kualitatif, dan R\&D). Bandung : Alfabeta. 2015 